\title{
Contributors to Volume 48, Number 2
}

Tim Brennen is a cognitive psychologist interested in memory for proper names, and the meaning of names for one's identity. He is coauthor of The Cognitive Psychology of Proper Names: The Importance of Being Ernest (1996). email: timb@psyk.uit.no

Robbins Burling is Professor Emeritus of Anthropology and Linguistics at the University of Michigan. His current interests are in social organization and kinship, sociolinguistics, the evolution of language and northeastern Indian ethnology. Among his publications are Rengsanggri: Family and Kinship in a Garo Village (2nd edition 1998) and The Strong Women of Modhupur (1997).

Anne Hvenekilde is professor of Norwegian as a second language, Department of Linguistics, University of Oslo, Blindern 1102, 0317 Oslo. Her interests are in second language acquisition, bilingualism, and the history of textbooks for first, second, and foreign language teaching. email: anne.hvenekilde@ilf.uio.no

David R. Johnson, professor of Sociology and Director of the Bureau of Sociological Research at the University of Nebraska-Lincoln, is interested in how marital quality changes over time, marital naming, and hormones and human mental disorders. email: djohnson2@unl.edu

Katherine Klingemann, a graduate of Doane College, is a social worker at David's Place in David City, Nebraska, 68632.

Caroline R. Marak is Head of the Department of Garo at NorthEastern Hill University, Chadmari, Tura 794002, Meghalaya, India. Her research has focused on aspects of Garo culture, especially language and art. She is the author of Influence of English on Garo Poetry.

Mariusz Rutkowski's onomastic interests include the use of names in closed communities, functions of proper names, the informal equivalents of names, and slang names. Mailing address: Uniwersytet Warmińsko-Mazurski, Instytut Filologii Polskiej, ul. Szrajbera 11, 10007 Olsztyn, Poland. email:rutkow@human.uwm.edu.pl

Laurie Scheuble is professor of Sociology at Doane College in Crete, NE 68333. Her current research is in marital name choices, children's naming, and wedding planning. She is also Deputy Editor of Teaching Sociology. email: 1scheuble@doane.edu

Noleen S. Turner is in the Department of Zulu at the University of Durban-Westville, Private Bag X54001, Durban 4000, South Africa. She has published in Nomina Africana, the South African Journal of African Languages, and elsewhere. email: nsturner@pixie.udw.ac.za 